\title{
GIS and Remote Sensing Studies in Lakes, Coastal Areas and Tracking Regions Most Vulnerable to Diseases
}

\author{
El-Alfy $\mathrm{MA}^{1 *}$ and Abou Hadied MM ${ }^{2}$ \\ ${ }^{1}$ Department of Marine Pollution, National Institute of Oceanography \& Fisheries, Alexandria, \\ Egypt \\ ${ }^{2}$ Department of Parasitology, National Institute of Oceanography \& Fisheries, Alexandria, Egypt
}

*Corresponding author: Muhammad A. El-Alfy, Marine Pollution, National Institute of Oceanography and Fisheries (NIOF), Alexandria, Egypt, Tel: 00201066226926; Email:

\section{Mini Review \\ Volume 4 Issue 2}

Received Date: April 24, 2020

Published Date: April 30, 2020

DOI: $10.23880 /$ ijoac-16000185

muhammad.elalfy@yahoo.com

\section{Abstract}

GIS and Remote sensing as new technologies can be used in such fields; environment, health care, civil engineering, agriculture...etc. Some author used these techniques in tracking pollutants, in biodiversity management and highlighting areas most vulnerable to diseases. In marine environment, some scientists make tracking to different organisms as dolphins using environmental DNA (eDNA) and use GIS in the geographic distribution of these organisms. These techniques consider addition to science and help governorates economically.

Keywords: GIS; Remote-sensing; Environment; Health

\section{Introduction}

Landsat data can aid in monitoring water quality parameters from high linking between the spectral signature of things on the Earth and band values of different sensors carried on the platform of satellite. El-Amier et al. [1] used statistical model for the knowledge of trophic state of Manzala and Burullus Lakes. The model could be considered for future expectation. Abd El-Hamid et al. [2] make model for prediction of the future situation of lake Edku, and found change in the area of different Land use/cover activities. El-Alfy et al. [3] studied land use/cover areas around three important drains, Manzala Lake. And linked between the impacts of these uses at the concentrations of heavy metals in this area. El-Alfy et al. [4] used kriging model of GIS to make spatial distribution of heavy metals in the surface water of Burullus Lake. Elnaggar and El-Alfy [5] mentioned areas most vulnerable to pollution from the distribution of physiochemical parameters of both water and sediments in different habitats (drains, openwater, shoreline and islets). Tayel et al. [6] also linked between the areas of some parameters within the concentration of $\mathrm{H} 2 \mathrm{~S}$ in the sediments of Burullus Lake. El-Alfy et al. [7] studied the toxicity of heavy metal and linked its serious environmental problems within the land cover and impacts between the studied areas at rosetta area of River Nile and Mediterranean sea.

Nowadays, GIS and RS are considered as better tools in veterinary Parasitology in order to understanding the epidemiology of parasite organisms, causing either snail/ arthropod borne diseases or direct transmissible diseases, mostly in small areas with a strong impact by man. GIS technologies serves as effective tools for data capture, mapping and analysis for the development of descriptive parasitological maps; fish disease monitoring and prediction of outbreaks, studying the environmental features that influence the distribution of parasites; predicting parasite occurrence/seasonally based on their environmental 
requirements and as decision support for disease intervention; and surveillance and monitoring of animal disease according to Cringoli et al. [8]; Parida et al. [9].

A considerable interest has been paid recently to epidemiologists and other scientists working in the geospatial health field to provide much needed data regarding the spatial and climatic parameters which determine the distribution limits of communicable parasitic diseases at various scales, Some beneficial impacts, in addition, were mapping the main Leishmania phlebotomine vector in the endemic focus of the Mt. Vesuvius in southern Italy [10].

Pollution now threaten the marine environment. Scientists work to develop group of satellites to the continuous monitoring of water quality in seas and oceans. Table (1) indicates the satellites and sensors could be used in water quality monitoring (Data acquired from NASA/ Applied Remote Sensing Training ARSET program)

\begin{tabular}{|c|c|c|}
\hline Landsat & Sensor & Resolution \\
\hline Landsat 7 & Enhanced Thematic Mapper (ETM+) & $185 \mathrm{~km}$, swath 15,30\&60 m (16 day revisit) \\
\hline Landsat 8 & Operational Land Imager (OLI) & $185 \mathrm{~km}$, swath 15,30 \&60 m (16 day revisit) \\
\hline Terra \& Aqua & Moderate Resolution Imaging Spectro-radiometer (MODIS) & $\begin{array}{c}2330 \mathrm{~km} \text {, swath 250m, 500m, 1km; } 1-2 \text { day } \\
\text { revisit. }\end{array}$ \\
\hline
\end{tabular}

Table 1: Satellites and sensors for monitoring water quality.

Field and Laboratory requirements aren't easy at all times so integration Remote sensing (RS) and GIS shortened the knowledge of earth situation.

\section{Some Applications for New Techniques in the Field of Marine Environment}

- Oil spills from ships, near petroleum industries distributed along the coastal areas

- Monitoring of algal blooms, chlorophyll and sea surface temperature.

- Changes in shoreline and Management [11].

- Suitability analyses for Aquaculture, fish farming, breeding and Biodiversity

- Tracking the line of moving way of organisms

- Spatial distribution of Pollutants \& highlighting the area's most vulnerable to pollution [12].

- Change in areas of Lakes (there are two new searches about change of areas in Manzala and Burullus Lake, Egypt). The water body area of Manzala Lake decreased from $53 \%$ to $46 \%$ in the year 1992 to 2019 , respectively [13]. Also the percent of chlorophyll changed in the trend from 2000 to 2018 based on the extracted Chlorophyll maps according to band values being used in the equation of Brivio et al. [14] and [15].

- Climatology and weather

- Islets and vegetative areas for keep the coastal areas landscape
Where, in Health and Human Services alone GIS has a wide range of applications

- GIS provides a common analytical framework in which public health authorities can understand problems and formulate a response, improving incident management and health planning.

- GIS is becoming a vital tool for scientists and public health officials investigating the cause and spread of deadly diseases around the world.

- Outbreaks of infectious diseases such as SARS and Corona can be quickly analyzed using GIS tools

- In tracking the areas most vulnerable to diseases in human, veterinary and plant disease mapping and forecasting.

\section{Considerations}

- Consideration of RS \& GIS results can solve many environmental problems

- Mapping play role in the development direction line of lakes

- Using new technologies in different authorities to be used in broad scope (environment, engineering, agriculture, fisheries, oceanography, infectious diseases ...etc)

- Support farmers to take preventive measures, but also would help policy makers to take contingent plans to prevent a huge economic loss due to fish mortality. 
Geospatial techniques comprising of RS \& GIS Remote Sensing (RS) \& Geographical Information-System (GIS)

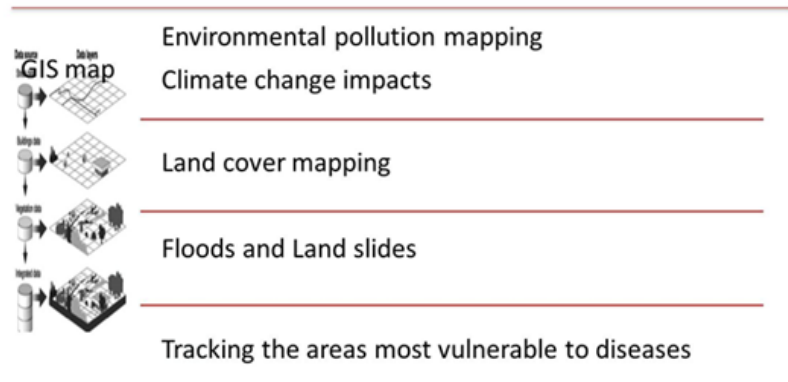

Figure 1: Geospatial techniques comprising of RS \& GIS.

\section{References}

1. El-Amier YA, Elnaggar AA, El-Alfy MA (2016) Investigation of Eutrophication State of Manzala and Burullus Lakes in Egypt by using Remote Sensing and GIS. Journal of Environmental Science and Pollution Research 2(4): 121-125.

2. Abd El-Hamid HT, El-Alfy MA, Elnaggar AA (2020) Prediction of future situation of land use/cover change and modeling sensitivity to pollution in Edku Lake, Egypt based on geospatial analyses. GeoJournal.

3. El-Alfy MA, El-Amier YA, El-Eraky TE (2020) Land use/ cover and eco-toxicity indices for identifying metal contamination in sediments of drains, Manzala Lake, Egypt. Heliyon 6(1):1-9.

4. El-Alfy MA, Abd El-Azim H, El-Amier YA (2017) Assessment of heavy metal contamination in surface water of Burullus Lagoon, Egypt. Journal of Scientific Agriculture 1: 233-243.

5. Elnaggar A, El-Alfy M (2016) Physiochemical Properties of Water and Sediments in Manzala Lake, Egypt. Journal of Environmental Sciences 45(2) : 157-174.

6. Tayel FT, Radwan AM, Morsy AM, Abd El-Halim AM, Al-Prol AE (2018) Relation of Someydrochemicals with Hydrogen Sulphide Levels in Sediments of Lake Burullus, Egypt. Asian Journal of Geographical Research 1(2): 1-11.
7. El-Alfy MA, Hasballah AF, Abd El-Hamid HT, El-Zeiny AM (2019) Toxicity assessment of heavy metals and organochlorine pesticides in freshwater and marine environments, Rosetta area, Egypt using multiple approaches. Sustainable Environment Research 29: 19.

8. Cringoli G, Rinaldi L, Veneziano V, Andand Musella $V$ (2005) Disease mapping and risk assessment in veterinary parasitology: some case studies. Parassitologia 47(1): 9-25.

9. Parida PK, Sahoo AK, Mohanty PM (2019) GIS applications in fish diseasemapping and forecasting. Advances in Fish Research, Narendra Publishing House, New Delhi, pp: 355-369.

10. Bergquist R (2006) Preface. Geospatial Health 1: 1.

11. Dewidar KH, Frihy O (2010) Automated techniques for quantification of beach change rates using Landsat series along the North-eastern Nile Delta, Egypt. Journal of Oceanography and Marine Science 1(2): 028-039.

12. El-Amier YA, Elnaggar AA, El-Alfy MA (2017) Evaluation and mapping spatial distribution of bottom sediment heavy metal contamination in Burullus Lake, Egypt. Egyptian Journal of Basic and Applied Sciences 4(1): 5566.

13. Haflz MA, Abd El-Hamid H, Darwish D, Basiony A, Abou Hadied M, et al. (2019) Tracking Environmental Changes in Manzala Lake Integrating Landsat Data Based on Interpolation Nonlinear Models. Int J Oceanogr Aquac 3(4): 000176.

14. Brivio P, Giardino C, Zilioli E (2001) Determination of chlorophyll concentration changes in Lake Garda using an image-based reductive transfer code for Landsat TM images. International Journal of Remote Sensing 22(2): 487-502.

15. Abd El-Hamid HT, Hafiz MA, Muhammad A El-Alfy, Wang W, Qiaomin Li (2019) Remote Sensing Technology for Studying the Impact of Anthropogenic Activities on the Environmental Change of Burullus Lake, Egypt. Advances in Ecological and Environmental Research 4(10): 269-285. 